\title{
KONSEP KALÂLAH DALAM ALQURAN DAN PENAFSIRANNYA MENURUT SUNI DAN SYIAH IMÂMIYYAH
}

\author{
Evra Willya \\ Sekolah Tinggi Agama Islam Negeri (STAIN) Manado \\ Jl. DR. SH. Sarundajang Kawasan Ringroad I Manado \\ E-mail: evrawillya@ymail.com
}

\begin{abstract}
Kalâlah in Alquran and Its Interpretation According to Suni and Syiab Imâmiyyah. This article is aimed to analyze the meaning of walad in the inheritance of kalâlah in Alquran. Islamic jurists have different vews in interpreting the meaning of walad in kalâlah inheritance. Walad in kalâlah inheritance gives the influence to the siblings inheritance. This article attempts to discuss critically and impartially the meaning of walad. By using comparative method, the writer analyzes the meaning of walad from the Suni and Syiah Imâmiyyah perspective. The writer concludes that there is no consensus among Islamic Scholars in interpreting the meaning of walad, by which for the Suni Scholars, the meaning of walad is only brothers of the heir, whereas for the Syiah Imamiyyah include the heir's sisters. This different opinion influences the regard of the two mainstreams towards the status of brother and sister in the inheritance of kalalah.
\end{abstract}

Keywords: inheritance, kalâlah, walad, Suni, Syiah Imâmiyyah

\begin{abstract}
Abstrak. Konsep Kalâlah dalam Alquran dan Penafsirannya Menurut Suni dan Syiab Imâmiyyah. Artikel ini menganalisis makna walad dalam kewarisan kalâlah yang terdapat dalam Alquran. Para mufassir berbeda pendapat tentang makna walad dalam kewarisan kalâlah. Walad dalam kewarisan kalâlah berpengaruh terhadap kewarisan saudara. Tulisan ini menguraikan makna walad secara kritis, komprehensif dan seimbang. Dengan menggunakan metode komparatif, pengertian walad dilihat dari perspektif Suni dan Syiah Imâmiyyah. Penulis menyimpulkan bahwa para ulama berbeda pendapat tentang pengertian walad. Ulama Suni berpendapat bahwa walad itu hanya anak lakilaki, sedangkan ulama Syiah Imâmiyyah menyatakan bahwa walad itu adalah anak laki-laki dan perempuan. Perbedaan pendapat ini sangat mempengaruhi sikap kedua aliran tersebut terhadap status saudara dalam kewarisan kalâlah.
\end{abstract}

Kata Kunci: waris, kalâlah, walad, Suni, Syiah Imâmiyyah

\section{Pendahuluan}

Keberadaan walad dalam kalâlah menempati posisi yang pasti sebagai orang yang berhak menerima harta warisan dan mempengaruhi hak orang lain dalam pembagian harta warisan. Lafaz walad dalam ayat waris lebih banyak digunakan berkaitan dengan masalah hijab-menghijab, baik dalam hijab hirmân maupun nuqshân, sehingga keberadaan walad adalah kalâlah atau menyebabkan saudara tidak mendapat warisan.

Perbedaan pendapat di kalangan ulama dalam memahami lafaz walad muncul ketika menafsirkan surat al-Nisầ [4]: 176:

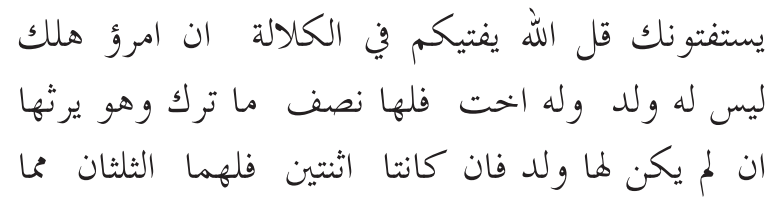

Naskah diterima: 20 Agustus 2013, direvisi: 30 September 2013, disetujui untuk terbit: 10 November 2013.

$$
\begin{aligned}
& \text { ترك وان كانوا اخوة رجالا ونساء فللذكر مثل حظ } \\
& \text { الانثيين.... - الماك }
\end{aligned}
$$

Mereka minta fatwa kepadamu (tentang kalâlah), katakanlah: "Allah memberi fatwa kepadamu tentang kalâlah yaitu seseorang yang meninggal dunia (dalam keadaan) tidak mempunyai anak dan mempunyai saudara perempuan maka bagian saudara perempuannya itu seperdua dari harta yang ditinggalkannya. Dan saudara laki-lakinya mewarisinya (seluruh harta saudara perempuan) jika ia tidak mempunyai anak. Tetapi jika saudara perempuan itu dua orang maka keduanya (mendapat) dua pertiga dari harta yang ditinggalkan. Dan jika mereka (ahli waris itu) terdiri atas saudara laki-laki dan perempuan maka bagian saudara laki-laki sebanyak bagian dua orang saudara perempuan... (Q.s. al-Nisâ'[4]: 176)

Adanya perbedaan pendapat tentang makna walad ini disebabkan oleh dua hal, yaitu: (1) Lafaz walad dihubungkan dengan kalâlah. Allah secara tegas menyatakan bahwa kalâlah adalah seseorang yang meninggal dalam keadaan tidak meninggalkan walad. 
Apabila dihubungkan dengan peristiwa sabab nuzûl ayat tersebut yaitu ketika 'Umar meminta penjelasan kepada Nabi tentang kalâlah yang terdapat dalam Q.s. al-Nisâ'[4]: 12 maka hal ini menunjukkan bahwa orang sama sekali tidak mengetahui makna kalâlah, atau mereka sudah mengetahui kalâlah tetapi apa yang telah mereka ketahui itu salah sehingga turun ayat Alquran yang menjelaskannya. (2) Memahami Hadis Ibn Mas' ûd yang menjelaskan bahwa saudara perempuan menjadi asabat ketika bersama dengan anak perempuan dan juga dalam memahami Hadis Jâbir bahwa Rasulullah Saw. memberikan hak waris kepada saudara laki-laki ketika bersama dengan anak perempuan.

Mayoritas ulama Suni mengartikan walad dengan anak laki-laki sehingga makna kalâlah adalah orang yang meninggal dalam keadaan tidak meninggalkan anak laki-laki dan ayah. Adapun Syiah Imâmiyyah mengartikan kata walad dengan anak laki-laki dan perempuan sehingga kalâlah diartikan dengan orang yang meninggal yang tidak meninggalkan anak laki-laki dan anak perempuan serta orang tua (ayah dan ibu).

Disamping anak laki-laki, cucu dari keturunan lakilaki juga diakui sebagai walad. Penarikan keturunan melalui garis laki-laki dapat dilihat dalam beberapa syair Arab. Hal ini diperkuat lagi dengan adanya Hadis yang memberikan hak waris kepada saudara perempuan atau saudara laki-laki ketika ada anak perempuan. Hadis yang menjelaskan kasus kewarisan anak perempuan Sa'ad merupakan hadis yang sangat populer di kalangan mayoritas ulama dan sering dikutip sebagai dalil bahwa Q.s. al-Nisầ[4]: 11 dan 12 merupakan ayat kewarisan pertama yang turun secara terperinci dan untuk menunjukkan bahwa saudara laki-laki berhak menjadi asabat ketika bersama dengan anak perempuan. Begitu pula dengan Hadis Ibn Mas'ûd yang memberikan hak waris kepada saudara perempuan ketika bersama dengan anak perempuan. Dalam hadis ini saudara perempuan berhak menghabiskan sisa harta.

Dalam Hadis ini terlihat bahwa anak perempuan tidak dapat menghijab saudara perempuan atau saudara laki-laki sehingga walad yang mempengaruhi kewarisan kalâlah itu adalah anak laki-laki saja. Keberadaan anak perempuan tidak mempengaruhi kalâlah. Pemahaman seperti ini muncul karena penggunaan kata walad untuk anak laki-laki sudah menjadi urf di kalangan orang Arab sehingga kalau dikatakan walad maka maksudnya adalah anak laki-laki. Mayoritas ulama menjadikan Hadis ini sebagai penjelas dari arti kalalah yang terdapat dalam Q.s. al-Nisầ[4]: 176.

Syiah Imâmiyyah tidak membedakan anak lakilaki dan anak perempuan. Bagi mereka, anak laki-laki dan perempuan mempunyai hak yang sama dalam kewarisan karena lafaz walad berasal dari wilâdah yang pengertiannya mencakup anak laki-laki dan anak perempuan. Q.s. al-Nisầ [4]: 176 sudah dapat menjawab persoalan kalâlah sehingga Hadis tidak diperlukan lagi. Lafaz walad dalam Alquran adalah untuk anak laki-laki dan anak perempuan. Alquran menggunakan kata $i b n$ kalau yang dikhususkan untuk anak laki-laki saja dan kata bintun yang dikhususkan untuk anak perempuan. Sedangkan untuk keduanya, yaitu anak laki-laki dan perempuan, digunakan kata walad. Karena kedudukan anak perempuan sama dengan anak laki-laki maka jika anak laki-laki dapat menghijab saudara laki-laki, anak perempuan pun dapat menghijabnya.

\section{Konsep Dasar Kalâlah}

Kata "kalâlah" adalah bentuk masdar dari kata "kalla" yang secara etimologi berarti letih atau lemah. Kata kalâlah pada asalnya digunakan untuk menunjuk pada sesuatu yang melingkarinya serta tidak berujung ke atas dan ke bawah, seperti kata "iklil" yang berarti mahkota karena ia melingkari kepala. Seseorang dapat disebut kalâlah manakala ia tidak mempunyai keturunan dan leluhur (anak dan ayah). Kerabat garis sisi disebut kalâlah karena berada di sekelilingnya, bukan di atas atau di bawah. ${ }^{1}$ Kemudian kata kalâlah digunakan untuk seseorang yang tidak mempunyai ayah dan anak. $^{2}$

Penggunaan istilah kalâlah bisa untuk pewaris dan ahli waris. Ada pendapat beberapa ahli bahasa tentang pewaris yang kalâlah, yaitu: (1) Orang yang tidak mempunyai anak dan orang tua. (2) Orang yang tidak mempunyai keluarga dan kerabat. (3) Orang yang meninggal. (4) Orang yang tidak mempunyai anak, orang tua dan saudara. ${ }^{3}$ Ahli waris yang kalâlah adalah saudara seibu dan saudara seayah. Saudara seibu disebut dengan kalâlah ibu dan saudara seayah disebut dengan kalâlah ayah.

Al-Thabarî menjelaskan bahwa terdapat perbedaan terhadap bacaan yûrats. Mayoritas umat Islam membaca wa in kâna rajulun yûrats kalâlatan dan sebagian yang lain membaca wa in kâna rajulun yûrits kalâlatan. Arti kedua bacaan ini tidak berbeda dan tetap memberikan

${ }^{1}$ Ibn Manzhûr, Lisân al-Arab, (Bayrût: Dâr al-Fikr, t.t.), Jilid XV, h. 142; Muhammad Rawwâs Qal'ah Jî dan Hâmid Shâdiq Qunaybî, Mu'jâm Lughah al-Fuqahâ,, (Bayrût : Dâr al-Nafs, 1998), h. 50; Muhammad Yûsuf Mûsâ, Al-Tirkah wa al-Mîrâts fî al-Islâm, (Mesir: Dâr al-Kitâb al-'Arabî, 1959), h. 201.

${ }^{2}$ Al-Âlûsî al-Baghdâdî, Rûh al-Ma'ânî, (T.tp: Dâr al-Fikr, t.th), h. 358.

${ }^{3}$ Ibn al-'Arabî, A $\underline{\text { kâm }}$ al-Qur'ân, (Bayrût: Dâr al-Fikr, 1998), Jilid II, h. 448. 
bagian kepada saudara laki-laki atau saudara perempuan seibu ${ }^{4}$ sehingga kalâlah adalah mereka yang mewarisi dari orang yang meninggal dengan pengecualian pada ibu, bapak dan anak. ${ }^{5}$

Ibnal-'Arabîmenyatakanbahwazahirayat menjelaskan kalâlah adalah orang yang tidak mempunyai ayah dan anak laki-laki serta meninggalkan saudara. Kalâlah adalah nama yang ditetapkan secara bahasa. Diantara makna kalâlah yang ditetapkan secara bahasa itu salah satunya dipakai untuk pengertian secara syarak. Q.s. alNisâ'[4]: 176 menamakan pewaris dengan kalâlah dan menyebutkan bagian-bagian yang akan diterima oleh para ahli waris. Ayah dan anak tidak disebutkan dalam ayat tersebut. Ibn al-'Arabî meyakini bahwa inilah yang dimaksud oleh Allah dengan kalâlah. Pengertian seperti ini menunjukkan bahwa pengertian musytaq (maknamakna kalâlah yang lain) menghendaki itu seluruhnya dan pengertian secara bahasa pun mutlak menghendaki yang demikian. ${ }^{6}$

Dari penjelasan di atas dapat dipahami bahwa pengertian kalâlah secara terminologi mengikuti pengertian kalâlah secara etimologi. Ini berarti bahwa makna kalâlah diambil dari pengertiannya secara bahasa. Oleh karena itu dapat dikatakan bahwa kalâlah adalah seseorang yang meninggal dan tidak meninggalkan ayah dan anak.

Berbeda dengan pendapat di atas, David S. Powers menyatakan bahwa ahli waris yang kalâlah adalah menantu perempuan. Menurutnya, akar kata "kâf-lâmlâm" muncul pada sejumlah bahasa Semitis selain bahasa Arab termasuk bahasa Akkad, Aram, Syiria dan Ibrani. Dalam empat bahasa terakhir ini, kata yang cocok dengan bahasa Arab kalâlah berfungsi sebagai istilah untuk kerabat perempuan. Dalam bahasa Aram, kallatu, yang muncul pada sejumlah prasasti hukum berarti seorang perempuan muda yang didapat oleh kepala sebuah rumah tangga sebagai istri untuk anak laki-laki yang hidup di dalam rumah tangga itu, atau ia adalah seorang menantu perempuan. Dalam keadaan tertentu kata kallatu juga berarti saudari ipar. Sementara dalam bahasa Aram dan Syiria ada kata "kallta" dan bahasa Ibrani "kallah" yang berarti menantu perempuan dan juga seorang pengantin putri.

Kemiripan antara kata-kata kallatu, kallta serta kallah di satu pihak dan kalâlah di pihak lain melahirkan kemungkinan yang menarik bahwa istilah Arab "kalâlab"

${ }^{4}$ Abû Ja'far Muhammad ibn Jarîr al-Thabarî, Jâmi' al-Bayân 'an Ta’wîl Ayy al-Qur'ân, (Bairût : Dâr al-Fikr, 1988), Jilid IV, h. 283.

${ }^{5}$ Abû Ja'far Muhammad ibn Jarîr al-Thabarî, Jâmi' al-Bayân 'an Tảwîl Ayy al-Qur'ân, h. 286.

${ }^{6}$ Ibn al-'Arabî, A A kâm al-Qur'ân, h. 449. yang artinya tidak jelas bagi khalifah 'Umar sebenarnya adalah kosa kata pinjaman dari bahasa Semitis lain. Dalam kasus ini, selama masa hidup Rasulullah Saw. dan sesudah wafatnya, kata kalâlah mungkin berfungsi sebagai istilah untuk kerabat perempuan yang nilai semantisnya mencakup satu atau lebih dari konsep pengantin perempuan, menantu perempuan dan saudari ipar. ${ }^{7}$

David S. Powers berpendapat bahwa bacaan yûrats yang ada pada Q.s. al-Nisâ'[4]: 12 adalah yûrits berarti seseorang yang mati dengan tidak meninggalkan orang tua dan anak. Ayat ini membicarakan sebuah kasus dimana kerabat sedarah terdekat orang yang meninggal yang masih hidup menerima bagian yang jumlahnya tidak ditentukan.

Kemudian Q.s. al-Nisầ[4]: 176 dibuka dengan menyinggung suatu pertanyaan yang tidak disebutkan tentang apa yaitu yastaftûnak yang ditanyakan kepada Nabi oleh para sahabatnya. Allah tiba-tiba memerintahkan kepada Nabi bagaimana menjawab pertanyaan sahabat tersebut dengan qul Allâh yuftîkum fì al-kalâlah. Perujukan pertanyaan ini pada kalâlah menunjukkan adanya hubungan antara ayat ini dan ayat $12 .{ }^{8}$ Berdasarkan hal ini, David S. Powers menyatakan bahwa makna Q.s. al-Nisâ [4]: 12 dan 176 bukanlah tipe saudara/saudari yang berubah dari ayat pertama ke ayat berikutnya seperti yang umum dipercaya tetapi keadaan yang dihadapi oleh saudara/saudari itu yang berubah. Ayat pertama memberikan kompensasi kepada saudara/ saudari yang terhapus hak warisnya dengan memberi mereka bagian (fardh) kecil warisan, sedangkan ayat kedua membenarkan pemberian itu dengan cara menunjukkan hak waris saudara/saudari atas warisan. Oleh karena itu tidak perlu lagi diadakan pembedaan antara saudara/saudari seibu dengan saudara/saudari seayah dan sekandung. ${ }^{9}$

\section{Kalâlah dalam Pandangan Suni}

Dalam Alquran ditemukan kata "walad" sekitar tiga puluh tiga kali dalam bentuk mufrad (singular) dan sekitar dua puluh tiga kali dalam bentuk jamak (plural). ${ }^{10}$ Khusus dalam ayat-ayat waris yang menyebutkan hak anak-anak terdapat delapan kali kata

\footnotetext{
${ }^{7}$ David S. Powers, Studies in Qur'an and Hadith The Formation of The Islamic Law of Inheritance, (London: University of California Press, 1979), h. 41.

${ }^{8}$ David S. Powers, Studies in Qur'an and Hadith The Formation of The Islamic Law of Inheritance, h. 28.

${ }^{9}$ David S. Powers, Studies in Qur'an and Hadith The Formation of The Islamic Law of Inheritance, h. 44.

${ }^{10}$ Muhammad Fuâd 'Abd al-Bâqî,, Müjam Al-Mufahras li Alfâzh al-Qur'ân al-Karîm, (T.tp: Dâr al-Fikr, 1981), h. 763-764; Amir Syarifuddin, Permasalahan dalam Pelaksanaan Faraid, (Padang:
} 
walad dan satu kali kata awlâd. Keseluruhan kata itu maknanya adalah anak laki-laki dan anak perempuan. Adapun penggunaan kata $i b n$ tidak ada hubungannya dengan kewarisan seperti ibn Maryam yang disebutkan lebih dari dua puluh tiga kali, ibn sabîl sekitar delapan kali dan ibnu Allâh sebanyak dua kali. ${ }^{11}$ Dan kata ibnatun (anak perempuan) secara khusus digunakan sebanyak dua kali ${ }^{12}$ tetapi tidak ada hubungannya dengan hak-hak yang diperoleh seperti ibnatu 'Imrân. Penggunaan ibnu sabîl menunjukkan bahwa meskipun menurut lahirnya digunakan kata mudzakkar namun artinya tetap menjangkau kepada perempuan juga. ${ }^{13}$

Ulama telah sepakat dalam memahami kata walad yang enam kali disebutkan dalam Q.s. al-Nisâ'[4]: 11 dan 12 serta satu kali kata awlâd adalah anak laki-laki dan anak perempuan. Dengan demikian, walad yang dapat mengurangi hak ibu dari sepertiga menjadi seperenam, hak suami dari seperdua menjadi seperempat dan hak istri dari seperempat menjadi seperdelapan adalah anak laki-laki dan anak perempuan. Begitu pula yang menetapkan ayah mendapat seperenam waktu tidak ada walad maksudnya adalah anak laki-laki dan anak perempuan.

Namun dalam memahami kata walad yang disebutkan dua kali dalam ayat 176 ulama tidak sepakat. Kata walad disebutkan di sini sehubungan dengan persyaratan seseorang pewaris menjadi kalalah. Dalam ayat disebutkan bahwa seorang pewaris disebut kalâlah bila tidak meninggalkan walad. Hal ini berarti keberadaan walad menyebabkan saudara-saudara tidak berhak menerima warisan.

Di kalangan para sahabat terjadi perbedaan pendapat tentang kalalah ini. 'Umar pernah bertanya kepada Rasul mengenai kalâlah. Rasul menjawab: "Cukup engkau memahami sendiri akhir Q.s. al-Nisầ[4]: 176". Sebab turunnya (sabab nuzûl) ayat 176 ini adalah ketika Jâbir ibn 'Abd Allâh mengadukan masalahnya kepada Nabi sementara ia tidak mempunyai anak dan orang tua lagi. ${ }^{14}$

Ibn al-'Arabî menyatakan bahwa ketika 'Umar menanyakan tentang kalâlah kepada Rasul, maka

IAIN IB Press, 1999), h. 21; Amir Syarifuddin, Pelaksanaan Hukum Kewarisan dalam Lingkungan Adat Minangkabau, (Jakarta: Gunung Agung, 1984), h. 54.

${ }^{11}$ Muhammad Fuâd 'Abd al-Bâqî, Mưjam Al-Mufahras li Alfàzh al-Qur'ân al-Karîm, h. 136-137.

${ }^{12}$ Muhammad Fuâd 'Abd al-Bâqî, Mưjam Al-Mufahras li Alfâzh al-Qur'àn al-Karîm, h. 138.

13 Amir Syarifuddin, Permasalahan dalam Pelaksanaan Faraid, h.21.

${ }^{14}$ Ibn Katsîr, Tafsîr al-Qur'ân al-Azhîm, (Bayrût: Dâr al-Fikr, t.t), Jilid II, h. 635 dan Ibn Qayyim al-Jawziyyah, I'lâm al-Muwaqqiî̀n 'an Rabb al-Âlamîn, (Bayrût: Dâr al-Fikr, 1974), Jilid II, h. 234.
Rasul menjawab bahwa kalâlah itu cukup dipahami dari ayat terakhir surat al-Nisâ. Mendengar jawaban Rasul tersebut 'Umar menyatakan bahwa "Kalau saya berumur panjang maka akan menghukumi kalâlah dengan hukum yang dipahami oleh orang yang bisa dan tidak bisa membaca Alquran, yaitu bahwa kalâlah adalah orang yang tidak punya anak". ${ }^{15} \mathrm{Di}$ sini terlihat 'Umar tidak mempunyai keyakinan yang pasti tentang kalâlah, apakah tidak punya anak saja atau juga tidak punya ayah. Ketidakyakinan 'Umar ini terlihat ketika pendapatnya berbeda dengan pendapat Abû Bakr yang menyatakan bahwa kalâlah adalah orang yang meninggal dunia dalam keadaan tidak meninggalkan ayah serta anak dan inilah arti kalâlah yang masyhur di kalangan orang Arab. ${ }^{16}$ Rasyîd Ridhâ meriwayatkan tentang keraguan 'Umar ini dalam tafsirnya dan menguatkan pendapat mayoritas ulama yang menganggap kalâlah sebagai orang yang tidak meninggalkan anak laki-laki dan ayah. ${ }^{17}$

Dari penjelasan di atas dapat diketahui bahwa pada awalnya 'Umar berpendapat kalâlah adalah orang yang tidak mempunyai anak berdasarkan Q.s. al-Nisâ'[4]: 176 tetapi kemudian pendapat 'Umar dikritik oleh Abû Bakr yang memahami kalâlah berdasarkan pemahaman yang sudah ada di kalangan orang Arab yaitu anak lakilaki dan ayah. Kuat dugaan 'Umar merasa bahwa kalâlah adalah orang yang tidak mempunyai anak tetapi masih mempunyai orang tua seperti yang ditunjukkan oleh zahir Q.s. al-Nisâ’[4]: 176.

Apabila dihubungkan dengan peristiwa yang mendahuluinya yaitu orang-orang yang meminta penjelasan kepada Nabi tentang maksud kalâlah yang ada pada Q.s. al-Nisâ'[4]: 12 dapat diketahui bahwa kata kalâlah bukanlah kata yang dipakai secara luas ${ }^{18}$ atau dapat dipahami bahwa orang Arab sama sekali tidak mengetahui maksud kalâlah karena kalâlah belum pernah terjadi pada waktu itu. Disamping itu dapat juga diketahui bahwa orang Arab mengetahui maksud kalâlah tetapi pemahaman mereka salah sehingga turunlah Q.s. al-Nisâ[4]:176 untuk menjelaskan maksudnya.

Menanggapi pertanyaan 'Umar kepada Rasul tentang kalâlah, al-Jashshâsh berkesimpulan bahwa: (1) Kalâlah

\footnotetext{
${ }^{15}$ Ibn al-'Arabî, A $\underline{k} k \hat{a} m$ al-Qur'ân, h. 450 dan 653.

${ }^{16}$ Abû Bakr al-Jashshâsh, A $\underline{h} k a ̂ m$ al-Qur'ân, (Bayrût: Dâr al-Fikr, t.t), h. 86 .

${ }^{17}$ Muhammad Rasyîd Ridhâ, Tafsîr al-Qur'ân al- $\underline{H}$ akîm al-Syahîr bi al-Manâr, (Kairo: Maktabah al-Bakarah, t.t), JIlid IV, h.423; Muhammad 'Alî al-Sâyis, Tafsîr Âyât al-A $\underline{h} k \hat{a} m$,(t.tp: t.p, t.t), Jilid II, h. 49; Abû Bakr al-Jashshâsh, Abkkâm al-Qur'ân, h. 86.

${ }^{18}$ Amir Syarifuddin, Pelaksanaan Hukum Kewarisan dalam Lin kungan Adat Minangkabau, h. 62.
} 
tidak boleh dipahami berdasarkan makna etimologi semata tetapi perlu adanya kajian lebih mendalam. Kalau merupakan istilah yang biasa digunakan tentu 'Umar dapat langsung memahaminya karena ia adalah seorang ahli bahasa. (2) Jawaban Rasul tersebut merupakan izin kepada sahabat untuk mengijtihadkan lafaz-lafaz yang kurang jelas, disamping itu sebagai petunjuk bahwa Rasul tidak menjelaskan semua persoalan secara detail. (3) Jawaban tidak tegas ini memberikan petunjuk juga bahwa kasus kalâlah tidak terjadi pada masa Rasul. Pertanyaan 'Umar tersebut sekedar untuk menambah pengetahuan serta pemahaman terhadap maksud ayat bukan untuk menyelesaikan suatu kasus. ${ }^{19}$

Sahabat yang menyatakan bahwa anak perempuan termasuk ke dalam pengertian walad adalah Ibn Abbâs dan Zubayr. Jika orang yang meninggal meninggalkan anak perempuan dan saudara perempuan maka saudara perempuan tidak mendapatkan harta warisan karena Q.s. al-Nisấ[4]: 176 menyebutkan bahwa saudara akan mewarisi harta apabila orang yang meninggal tidak mempunyai anak. Maka, bukankah anak perempuan itu dinamakan juga anak sehingga saudara perempuan tidak mendapatkan apa-apa. Berbeda dengan kedua sahabat ini, mayoritas ulama berpendapat bahwa dalam kasus bersamanya anak perempuan dan saudara perempuan maka anak perempuan mendapat seperdua sebagai furûdh dan saudara perempuan mendapat seperdua sebagai asabat. ${ }^{20}$ Pendapat ini tidak terlepas dari pemahaman mereka yang menyatakan bahwa walad itu adalah anak laki-laki saja.

Rasyîd Ridhâ menjelaskan bahwa penyebab terjadinya perbedaan pemahaman tersebut karena saudara perempuan tidak mendapat apa-apa jika bersama anak laki-laki secara ijmak dan jika bersama anak perempuan maka ia mewarisi. Sedangkan yang lain berpendapat bahwa anak mencakup anak laki-laki dan anak perempuan sehingga saudara perempuan tidak mewarisi jika bersama dengan anak perempuan. ${ }^{21}$ Alasan yang dipakai oleh mayoritas ulama dalam menetapkan bahwa hanya anak laki-laki saja yang masuk ke dalam pengertian walad adalah Hadis Ibn Mas'ûd.22

${ }^{19}$ Abû Bakr al-Jashshâsh, A $\underline{b} k \hat{a} m$ al-Qur'ân, h. 88 dan Al Yasa Abu Bakar, Abli Waris Sepertalian Darah Kajian Perbandingan terhadap Penalaran Hazairin dan Penalaran Fikih Mazhab, (Jakarta: INIS, 1998), h. 46.

${ }^{20}$ Ibn Katsîr, Tafsìr al-Qur'àn al-Azhîm, h. 593.

${ }^{21}$ Muhammad Rasyîd Ridhâ, Tafsîr al-Qur'ân al- $\underline{H}$ akìm al-Syahîr bi al-Manâr, h. 109-110.

${ }^{22}$ Hadis yang dimaksud adalah:

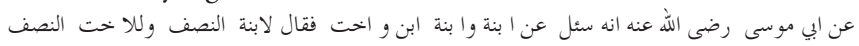

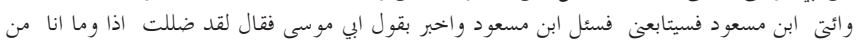

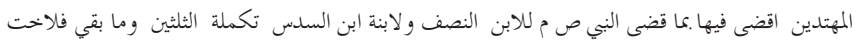

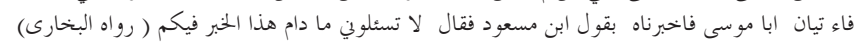

Dalam Hadis tersebut dijelaskan bahwa anak perempuan mewarisi bersama-sama dengan cucu perempuan dari anak laki-laki yang telah meninggal dan seorang saudara perempuan. Ibn Mas'ûd menetapkan bagian untuk seorang anak perempuan seperdua, untuk seorang cucu perempuan seperenam untuk menggenapkan dua pertiga dan sisanya untuk saudara perempuan.

Disamping Hadis ini, ada lagi Hadis lain yang dipakai oleh mayoritas ulama dalam menjelaskan bahwa anak yang dimaksud adalah anak laki-laki, yaitu Hadis Jâbir ibn 'Abd Allâh yang menyatakan bahwa istri Sa'ad ibn Rabî̀ datang menemui Rasulullah Saw. bersama dengan dua orang anak perempuannya. Istri Rabî̀ ini mengadu kepada Rasul tentang harta suaminya yang telah meninggal dunia dan diambil oleh saudara laki-laki suaminya. Maka Rasul memberikan kepada dua orang anak perempuan Sa'ad tersebut dua pertiga bagian, untuk ibu mereka seperdelapan dan sisanya untuk paman. ${ }^{23}$

Dari Abû Mûsâ Ra. bahwasannya ia ditanya tentang bagian seorang anak perempuan, cucu perempuan (melalui anak laki-laki yang telah meninggal) dan seorang saudara perempuan. Beliau menjawab: "Untuk anak perempuan seperdua, untuk saudara perempuan seperdua. Pergilah kepada Ibn Mas'ûd tentu ia pun akan mengikuti aku”. Ketika diajukan kepada Ibn Mas'ûd, dia menjawab: "Kalau begitu saya telah keliru dan tidak termasuk orang yang dapat petunjuk. Saya akan menyelesaikannya berdasarkan keputusan Nabi. Untuk seorang anak perempuan seperdua, untuk seorang cucu perempuan seperenam, untuk menggenapkan dua pertiga dan sisanya untuk saudara perempuan". Setelah itu kami kembali kepada Abû Mûsâ dan menceritakan penjelasan Ibn Mas'ûd tersebut. Abû Mûsâ menjawab: "Jangan tanyai aku selama orang alim itu masih ada”. (H.r. al-Bukhârî).

Lihat Al-Kirmânî, Shahîh al al-Bukhârî bi Syarh al-Kirmânî, (Kairo: alBâhiyyah al-Mishriyyah, 1937), Jilid 23, h. 162; Ibn Hajar al-'Asqalânî, Fath al-Bârî, (T.tp, Al-Maktabah al-Salafiyyah, t.t), Jilid 12, h. 17.

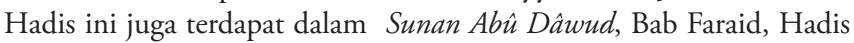
No.4; Sunan al-Tirmîdzî, Bab Faraid, Hadis No.4; Sunan Ibn Mâjah, Bab Faraid, Hadis No.6; Sunan al-Dârimî, Bab Faraid, Hadis No.7; Wensinck AJ, Mưjàm al-Mufahras li Alfâzh al-Hadîts, (Leiden: EJ Brill, 1967), Jilid 3, h. 515.

${ }^{23}$ Hadis yang dimaksud adalah:

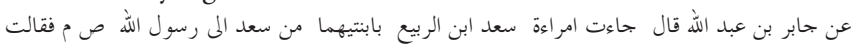

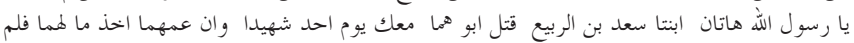

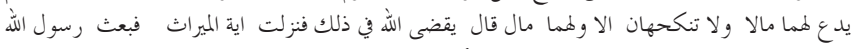

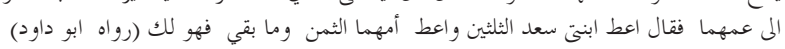
Jâbir ibn 'Abd Allâh mengatakan bahwa istri Sa’ad ibn Rabî beserta dua orang anak perempuannya datang kepada Rasul. Ia berkata: "Ya Rasul, ini dua orang anak perempuan Sa'ad, ayahnya telah mati syahid dalam perang Uhud dan paman mereka telah mengambil semua hartanya tanpa ada yang tersisa. Keduanya tidak akan menikah sekiranya tidak mempunyai harta". Rasul menjawab: "Allah akan memberikan keputusan”. Lalu turun ayat kewarisan. Rasul memanggil paman kedua anak tersebut dan berkata: "Berikan kepada kedua orang anak perempuan Sa'ad itu dua pertiga, untuk ibu mereka seperdelapan dan sisanya untukmu”. (H.r. Abû Dâwud).

Lihat Abû Dâwud, Sunan Ab̂̀ Dâwud, (Kairo: Mushtafhâ al-Bâb, 1952), h. 109. Menurut Ibn Katsîr, dalam Hadis ini terdapat nama 'Abd Allâh ibn Muhammad ibn Aqîl yang tidak diketahui keadaannya dan tidak ada riwayat apa pun tentang kualitas pribadinya. Nama ini 
Alasan selanjutnya adalah karena nasab anak ditarik melalui garis laki-laki, sebagaimana yang terdapat dalam sebuah syair Arab:

$$
\text { بنونا بنو ابنائنا وبنا تنا بنو هن ابناء الرجال الا باعد24 }
$$

Keturunan kita adalah anak laki-laki dan anak perempuan dari anak laki-laki kita, sedangkan anak dari anak perempuan adalah keturunan dari laki-laki lain.

Dari pemahaman mayoritas ulama tentang pengertian walad terlihat bahwa walad itu hanya untuk anak lakilaki saja serta keturunan dari anak laki-laki tersebut. Anak perempuan serta keturunannya tidak termasuk ke dalam pengertian walad. Pembatasan pewarisan hanya pada keturunan melalui garis laki-laki adalah aturan tentang nasab sedangkan keturunan dari anak perempuan dimasukkan ke dalam kelompok dzawî alarhâm.

Pandangan mayoritas Ulama Suni yang memasukkan keturunan dari anak perempuan sebagai dzawîal-arh $\underline{a} m$, menurut Hazairin, tidak dapat dilepaskan dari pengaruh kultur Arab yang patrilineal ${ }^{25}$ dan para pemikir Muslim klasik hidup dalam sosio kultural patrilineal. ${ }^{26}$

Oleh karena itu, Amir Syarifuddin melihat ada dua hal yang menyebabkan Ulama Suni mengartikan walad dengan anak laki-laki saja, yaitu: (1) Penggunaan secara urf dari kata walad. Dalam adat berbahasa Arab, walad diartikan dengan anak laki-laki saja. Mereka terpengaruh oleh adat jahiliyah dalam penggunaan kata sehingga terdorong untuk mengartikan kata walad tidak menurut umumnya. (2) Terpengaruh oleh Hadis Nabi yang disampaikan oleh Ibn Mas'ûd tentang pembagian waris untuk kasus anak perempuan, cucu perempuan dan saudara perempuan. ${ }^{27}$

hanya dikenal melalui Hadis yang diriwayatkannya. Ibn Katsîr, Tafsîr al-Qur'àn al-Azhim, h. 212. Hadis ini juga terdapat dalam Sunan alTirmîdzî, Bab Faraid, Hadis No.3 dan Musnad A hmad ibn Hanbal, Bab Faraid, Jilid 3, h. 252. Wensinck AJ, Mujâm al-Mufahras li Alfâzh al- Hadîts, Jilid 6, h. 552.

${ }^{24}$ Muhammad Rasyîd Ridhâ, Tafsîr al-Qur'ân al- $\underline{H}$ akîm al-Syahîr bi al-Manâr, Jilid 4, h. 405.

${ }^{25}$ Menurut Hazairin , masyarakat Arab, baik suku Quraisy maupun suku-suku Badui, menarik garis keturunan semata-mata melalui penghubung laki-laki sehingga menimbulkan ushbah-ishbah, banibani dan sebagainya dimana semuanya bersifat klan yang berdasarkan garis keturunan patrilineal. Dalam hubungan itu umumnya perkawinan orang Arab adalah eksogami, artinya dilarang mengawini anggota sebani atau se-'ushbah walaupun di beberapa tempat sewaktu turunnya Alquran telah dijumpai pula kemungkinan endogamy di tanah Arab sebagai pengecualian, seperti perkawinan endogamy antara orang tua (Nabi) Muhammad, antara (Nabi) Muhammad dengan Khadijah dan sebagainya. Hazairin, Hendak Kemana Hukum Islam, (Jakarta: Tintamas, 1976), h. 11-12.

${ }^{26}$ A. Sukris Sarmadi, Transendensi Keadilan Hukum Waris Islam Transformatif, (Jakarta: PT RajaGrafindo Persada, 1997), h. 4.

${ }^{27}$ Amir Syarifuddin, Permasalahan dalam Pelaksanaan Faraid, h. 22.
Persoalan selanjutnya adalah dimasukkannya ayah ke dalam pengertian kalâlah. Dalam penjelasan kata kalâlah yang terdapat pada Q.s. al-Nisâ'[4]: 176 tidak disebutkan ayah, tetapi tampaknya Ulama Suni memahami pengertian ayah dari pengembangan pengertian anak karena dekatnya kata walad dengan wâlid. ${ }^{28}$ Sulit menemukan argumen rasional yang digunakan oleh mufasir dan mayoritas ulama untuk memasukkan kata-kata wâlid atau ayah. Dalam hal ini kelihatannya mayoritas ulama pada waktu menghadapi ayat kalâlah yang zahirnya menjelaskan seseorang yang tidak meninggalkan anak memahaminya menjadi seorang yang tidak meninggalkan anak laki-laki dan ayah, karena sebelumnya mereka telah mempunyai konsep tentang arti kalâlah itu sendiri. Karena sulit menemukan argumentasi yang tepat kelihatannya mereka berbelit-belit dalam menjelaskan arti kalâlah secara etimologi dan 'urf serta menyimpulkan bahwa arti syarak mengikuti pada arti etimologi. ${ }^{29}$

Dari penjelasan di atas dapat diketahui bahwa kalâlah dalam pandangan Suni adalah orang yang meninggal dan tidak meninggalkan anak laki-laki serta ayah. Konsekuensinya adalah apabila seseorang meninggal dalam keadaan kalâlah maka saudara akan mendapat warisan meskipun anak perempuan ada. Karena menurut mayoritas Ulama Suni, anak perempuan tidak mempengaruhi atau menghijab saudara dalam keadaan pewaris kalâlah.

\section{Kalâlah dalam Pandangan Syiah Imâmiyyah}

Sebelum membahas lebih lanjut kalâlah dalam pandangan Syiah Imâmiyyah, terlebih dahulu akan dikemukakan sistem kewarisan mereka.

Menurut al-Thûsî ada dua bentuk kewarisan yaitu khâsh (khusus) dan 'âm (umum). Bentuk 'âm terjadi apabila seseorang meninggal tidak mempunyai ahli waris maka harta warisannya diserahkan ke Bayt alMâl dan yang mewarisinya adalah seluruh umat Islam. Sedangkan kewarisan dalam bentuk khâsh terbagi pada dua yaitu nasab dan sebab. Kewarisan karena nasab terdiri atas $d z \hat{u}$ al-furûdh dan $d z \hat{u} a l-q a r a ̂ b a h$, sedangkan kewarisan karena sebab terjadi karena perkawinan dan memerdekakan budak. ${ }^{30}$

Ahli waris karena hubungan nasab adalah para

28 Amir Syarifuddin, Pelaksanaan Hukum Kewarisan dalam Lingkungan Adat Minangkabau, (Jakarta: Gunung Agung, 1984), h. 61.

${ }^{29}$ Amir Syarifuddin, Permasalahan dalam Pelaksanaan Faraid, h. 24.

${ }^{30}$ Abû Ja'far Muhammad Husayn ibn 'Alî al-Thûsî, Al-Mabsûth fì Fiqh al-Imâmiyyah, (Taheran: Maktabah al-Murtadhawiyyah, t.t.), h. 69. 
kerabat. Kekerabatan terjadi karena adanya hubungan yang sah antara dua orang, baik keduanya berada dalam satu jalur hubungan seperti ayah ke atas atau anak ke bawah, maupun pada jalur yang memunculkan orang ketiga, yaitu saudara-saudara, paman dari pihak ayah dan paman dari pihak ibu. ${ }^{31}$

Para ahli waris karena hubungan nasab ini ada yang memperoleh harta warisan melalui $d z \hat{u}$ al-furûdh ${ }^{32}$ dan yang melalui $d z \hat{u}$ al-qarâbah. ${ }^{33}$ Syiah tidak memakai istilah asabat tetapi mereka menggunakan istilah $d z \hat{u} a l-$ qarâbah terhadap ahli waris yang mengambil sisa harta. Sebagaimana satu orang anak laki-laki mengambil seluruh harta warisan maka anak perempuan dan saudara perempuan yang sendirian pun juga mempunyai hak yang sama dengan mengambil seluruh harta. ${ }^{34}$

Sistem kewarisan Syiah Imâmiyyah tidak membedakan antara anak perempuan dan anak lakilaki kecuali dalam hal-hal yang telah ditentukan oleh Alquran. Pendapat mereka ini berpengaruh terhadap pengertian kalâlah. Kalâlah adalah seseorang yang meninggal dunia dan tidak meninggalkan orang tua serta anak. ${ }^{35}$ Syiah Imâmiyyah mengartikan walad dalam Q.s. al-Nisâ'[4]: 176 dengan anak laki-laki dan anak perempuan karena lafaz walad bersumber dari alwilâdah yang pengertiannya mencakup anak laki-laki dan anak perempuan. Tidak ada perbedaan antara anak laki-laki dan anak perempuan dalam memperoleh hak untuk mewarisi harta. Cucu, baik yang berasal dari anak

31 Muhammad Jawâd Mughniyyah, Al-Ahbwâl al-Syakhshiyyah, (Bayrût: Dâr al-Ilmi, t.t), h. 214.

${ }^{32}$ Kelompok ahli waris $d z \hat{u}$ al-furûdh adalah kelompok ahli waris yang bagian warisannya telah pasti. Mereka ini menerima bagian sebagaimana yang telah ditetapkan oleh Alquran, yaitu: (1) Seperdua, apabila ahli warisnya seorang anak perempuan, seorang saudara perempuan dan suami apabila tidak ada anak. (2) Seperempat, apabila ahli warisnya suami ketika ada anak atau istri ketika tidak ada anak. (3) Seperdelapan, apabila ahli warisnya istri ketika ada anak. (4) Dua pertiga, apabila ahli warisnya dua orang saudara perempuan kandung atau dua orang anak perempuan atau lebih. (5) Sepertiga, apabila ahli warisnya ibu ketika tidak ada anak laki-laki dari mayit atau ketika tidak ada saudara si mayit yang menghalanginya menerima bagian lebih dari seperenam. (6) Seperenam, apabila ahli warisnya kedua orang tua apabila ada anak atau ibu mewarisi bersama saudara-saudara atau seorang saudara laki-laki atau saudara perempuan seibu. Lihat Muhammad Jawâd Mughniyyah, Fiqh al-Imâm Jảfar al-Shâdiq, (Iran: Dâr al-I'tishâm, 1999), Jilid 6, h.197.

${ }_{33}$ Sedangkan $d z \hat{u}$ al-qarâbah adalah kelompok ahli waris yang memperoleh sisa harta setelah dibagikan kepada ahli waris $d z \hat{u}$ alfurûdh. Mereka adalah anak laki-laki atau perempuan, ayah apabila tidak ada anak, saudara kandung atau seayah yang terdiri atas saudara laki-laki atau perempuan atau laki-laki saja. Abû Ja'far Muhammad Husayn ibn 'Alî al-Thûsî, Al-Mabsûth fî Figh al-Imâmiyyah, h. 16.

34 Muhammad Jawâd Mughniyyah, Fiqih Lima Mazhab, diterjemahkan oleh Masykur, (Jakarta: Lentera Basritama, 2000), h. 555.

35 Muhammad Husayn al-Thabâ’thabẩi, Al-Mîzân fî̀ Tafsîr alQur'ân, (Bayrût: Muassasah al-Â'lamî, t.t.), Jilid 4, h. 227. laki-laki maupun anak perempuan, termasuk ke dalam pengertian walad. Dengan demikian, dalam perluasan pengertian makna walad kepada cucu harus dipahami sebagai cucu yang berasal dari anak laki-laki dan anak perempuan. ${ }^{36}$

Cucu, baik pancar dari anak laki-laki maupun pancar anak perempuan, mendapatkan warisan apabila pewaris tidak mempunyai anak. Cucu mendapat bagian sebesar bagian orang yang mereka gantikan yaitu bagian cucu dari pancar anak laki-laki mendapat bagian dua kali dari bagian yang diperoleh cucu dari pancar anak perempuan. Tidak ada seorang pun di antara cucu yang berhak mewarisi bila terdapat salah seorang diantara anak laki-laki atau anak perempuan. Oleh karena itu, jika orang yang meninggal meninggalkan seorang anak perempuan dan cucu laki-laki dari anak perempuan maka seluruh harta untuk anak perempuan dan cucu tidak mendapat apa-apa.

Apabila ahli waris terdiri atas cucu laki-laki pancar anak laki-laki dan cucu perempuan pancar dari anak perempuan maka bagian cucu laki-laki pancar anak laki-laki adalah dua pertiga, sedangkan bagian cucu perempuan pancar anak perempuan mendapat sepertiga. Hal ini dapat dipahami karena cucu menempati kedudukan orang tua mereka masing-masing. Mereka juga dapat menghijab ahli waris pada tingkatan kedua dan ahli waris pada tingkatan ketiga.

Pengertian walad menurut ulama Syiah Imâmiyyah adalah anak laki-laki dan anak perempuan serta keturunan keduanya. Argumentasi yang diajukan oleh Ulama Syiah Imâmiyyah adalah lafaz walad merupakan musytaq (bersumber) dari al-wilâdahyang pengertiannya mencakup anak laki-laki dan anak perempuan. Alquran sendiri telah memakai lafaz tersebut untuk anak lakilaki dan anak perempuan, yaitu:

$$
\text { يوصيكم الله في اولادكم للذكر مثل حظ الانثيين }
$$

Allah telah mewasiatkan terhadap anak-anakmu bahwa seorang anak laki-laki mendapat dua bagian anak perempuan. (Q.s. al-Nisâ'[4]: 11)

$$
\text { ماكان لله ان يتخذ من ولد. }
$$

Allah tidak mempunyai anak (laki-laki dan perempuan) (Q.s. Maryam [19] : 35)

$$
\text { يايها الناس انا خلقناكم من ذكر و انثى }
$$

Hai manusia, sesungguhnya Kami telah menjadikan kamu semua dari seorang laki-laki dan perempuan. (Q.s.

${ }^{36}$ Abû Ja'far Muhammad Husayn ibn 'Alî al-Thûsî, Al-Mabsûth fì Fiqh al-Imâmiyyah, h. 69 dan Abû 'Alî al-Fadh ibn al-Hasan alThabrâsî, Majma' al-Bayân fî̀ Tafsîr al-Qur'ân, (Bayrût: Dâr al-Fikr, 1986), Jilid 3, h. 229. 


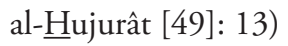

Dari ayat-ayat ini dapat dipahami bahwa walad itu mencakup anak laki-laki dan anak perempuan dan arti ini harus dipergunakan keduanya. Jika anak laki-laki menghalangi saudara laki-laki maka seharusnya anak perempuan juga menghalangi saudara laki-laki. ${ }^{37}$

Syiah Imâmiyyah menolak Hadis tentang asabat karena Hadis tersebut tidak sahih. Hadis yang dimaksud adalah:

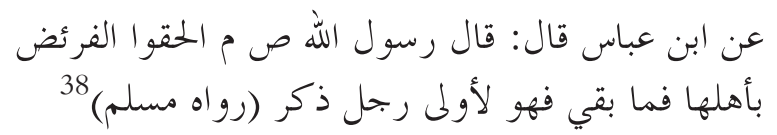

Dari Ibn 'Abbâs ia berkata, Rasulullah Saw. bersabda:

"Berikan bagian farâidh (warisan) kepada yang berhak, dan sisanya untuk kerabat laki-laki yang terdekat. (H.r.

Muslim)

Hadis Ibn 'Abbâs ini diriwayatkan oleh Thâwûs dan Syiah Imâmiyyah menganggap Hadis Thâwûs tidak kuat dan menolak penisbatannya kepada Nabi Saw. karena Thâwûs adalah orang yang daif (lemah) ${ }^{39}$

Hadis ini dipakai oleh mayoritas Ulama Suni dalam menetapkan anak perempuan menjadi asabat ketika bersama dengan saudara laki-laki. Anak perempuan mendapat seperdua dan sisanya diberikan kepada saudara laki-laki. Demikian pula halnya jika orang yang meninggal itu tidak mempunyai anak tetapi mempunyai seorang saudara perempuan tanpa saudara laki-laki dan mempunyai seorang paman maka saudara perempuan mengambil bagian seperdua sebagai furûdh sedangkan seperdua lagi diberikan kepada paman, karena paman adalah orang yang paling dekat hubungannya dengan mayat sesudah saudara perempuan. Sedangkan menurut Syiah, saudara laki-laki dan paman tidak mendapat warisan. ${ }^{40}$

Ketentuan seperti ini terjadi apabila mayat meninggalkan seorang anak perempuan atau lebih tetapi tidak mempunyai anak laki-laki atau bahkan tidak mempunyai anak seorang pun, baik laki-laki maupun perempuan, tetapi mempunyai seorang saudara perempuan atau lebih serta tidak mempunyai saudara laki-laki namun mempunyai seorang paman (saudara ayah). Mayoritas Ulama Suni menempatkan saudara laki-laki mayat sebagai penerima warisan

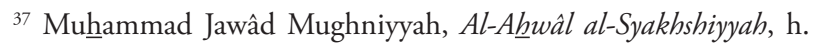
233.

${ }^{38}$ Hadis ini juga terdapat dalam Shahîh al al-Bukhârî, Bab Faraid, Hadis No. 5, 7, 9 dan 15; Sunan al-Tirmîdzî̀, Bab Faraid, Hadis No. 8 dan Sunan al-Dârimî, Bab Faraid, Hadis No.28.

${ }^{39}$ Muhammad Jawâd Mughniyyah, Fiqh al-Imâm Ja'far al-Shâdiq, h. 203.

${ }^{40}$ Muhammad Jawâd Mughniyyah, Al-Ahwâl al-Syakhshiyyah, h. 233. bersama-sama dengan seorang anak perempuan atau lebih. Jika bersama anak perempuan maka saudara laki-laki mengambil bagian setengah, sedangkan bila bersama dengan dua orang anak perempuan atau lebih maka ia mendapat sepertiga. Ini diberlakukan pula kepada paman yang menyertai seorang saudara perempuan atau beberapa orang saudara perempuan. Syiah Imâmiyyah menyatakan bahwa asabat seperti ini tidak benar. Bagian yang tersisa sesudah diambil secara furûdh wajib diserahkan kepada pemilik bagian furûdh yang terdekat dengan orang yang meninggal. Dengan demikian, seluruh harta diberikan kepada seorang anak perempuan atau beberapa orang anak perempuan, sedangkan saudara laki-laki mayit tidak mendapat sama sekali. Begitu juga halnya dengan saudara perempuan dan paman, seluruh harta diberikan kepada saudara perempuan sehingga paman tidak mendapat bagian dari harta warisan karena saudara perempuan lebih dekat hubungan kekerabatannya dengan mayit dibandingkan paman. $^{41}$

Dalam menolak adanya asabat, disamping Hadis Ibn 'Abbâs tersebut, mereka juga berargumen dengan Q.s al-Nisầ[4]: 7:

$$
\begin{aligned}
& \text { للرجال نصيب مما ترك الوالدان و و الأقربون وللنساء }
\end{aligned}
$$

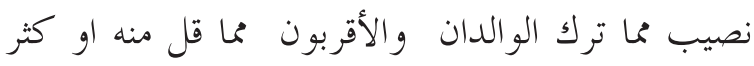

$$
\begin{aligned}
& \text { نصيبا مفروضاب نما ترو }
\end{aligned}
$$

Bagi laki-laki ada bagian dari harta peninggalan ibubapaknya dan kerabatnya dan bagi perempuan ada bagian pula dari harta peninggalan ibu-bapak dan kerabatnya baik sedikit maupun banyak sebagai bagian yang telah ditetapkan. (Q.s al-Nisầ [4]: 7)

Ayat ini menunjukkan adanya persamaan hak antara laki-laki dan perempuan dalam hal mendapatkan harta warisan karena ayat dengan jelas menyatakan lakilaki dan perempuan sama-sama mendapat bagian. Kalau ditetapkan adanya asabat berarti membedakan kedudukan antara laki-laki dan perempuan.

Dari penjelasan di atas terlihat bahwa Syiah Imâmiyyah mempergunakan makna kebahasaan dalam memahami walad sebagai anak laki-laki dan anak perempuan sehingga dalam perluasan pengertian walad kepada cucu mereka memahaminya sebagai cucu yang berasal dari anak perempuan dan anak laki-laki. Penafsiran ini didasarkan pada ayat-ayat yang banyak mempergunakan walad untuk anak laki-laki dan anak perempuan.

Kultur Irak yang menjadi tempat timbulnya Syiah juga mempengaruhi dalam penerapan hukum mereka,

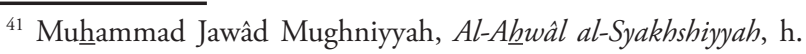
233. 
karena Irak merupakan tempat pertemuan peradabanperadaban kuno. Di sana terdapat pelbagai pengetahuan Persia dan Kaldan serta sisa-sisa peradaban kedua bangsa itu. Filsafat Yunani dan pemikiran Hindu pun masuk ke Irak. Pelbagai peradaban dan pemikiran itu bercampur di Irak sehingga menjadikan Irak tempat tumbuhnya pelbagai golongan dalam Islam, khususnya yang berhubungan dengan filsafat. Itulah sebabnya Syiah banyak dipengaruhi oleh pemikiran filosofis yang telah beradaptasi dengan alam pikiran Irak. Lebih dari itu, Irak merupakan tempat tumbuhnya pelbagai pengkajian ilmiah serta penduduknya memiliki kecerdasan dan kemampuan penguasaan ilmu pengetahuan. Abû Zahrah berpendapat bahwa Syiah telah dipengaruhi oleh pemikiran-pemikiran bangsa Persia dalam masalah kerajaan dan pewarisan. Kesamaan antara pemikiran mazhab mereka dan undang-undang kerajaan Persia sangat jelas. Kebanyakan penduduk Persia sampai sekarang adalah penganut Syiah dan penganut Syiah generasi pertama berasal dari Persia. ${ }^{42}$ Oleh karena itu dapat diketahui bahwa Irak dengan ibu kotanya Baghdad sebagai basis Syiah Imâmiyyah juga sebagai pusat kebudayaan dan peradaban yang banyak dikunjungi oleh bangsa lain yang pempunyai kebudayaan dan peradaban berbeda sehingga menyebabkan Irak menjadi negara yang heterogen dan boleh jadi dalam menetapkan hak waris mereka memandang bahwa anak perempuan memiliki hak yang sama dengan anak laki-laki.

Sesuai dengan pemahaman Syiah tentang kalâlah yaitu orang yang tidak mempunyai anak laki-laki dan anak perempuan serta orang tua maka orang tua yang dimaksud di sini adalah ayah dan ibu sehingga saudara tidak berhak mewarisi selama ada keturunan walaupun anak perempuan atau orang tua walaupun ibu. Allah telah menjelaskan dalam Q.s al-Nisầ[4] bahwa kalâlah adalah orang yang tidak mempunyai walad (anak lakilaki dan anak perempuan). Dimasukkannya wâlid ke dalam pengertian kalâlah karena memandang hubungan langsung (tidak ada perantara) antara anak, orang tua dan si mayat. Berhubung anak dan orang tua mempunyai kedekatan yang sama maka orang tua diberi hak menghijab kerabat garis sisi sebagaimana anak.

\section{Penutup}

Persoalan kalâlah berasal dari perbedaan ulama tentang pengertian walad yang terdapat dalam Q.s al-Nisâ'[4]: 176. Dari kajian komprehensif tentang kalâlah menurut Suni dan Syiah Imâmiyyah maka diperoleh kesimpulan bahwa mayoritas Ulama Suni

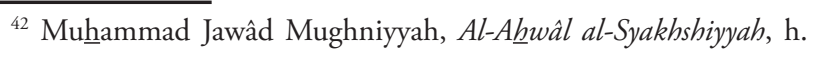

berpendapat bahwa walad yang terdapat pada Q.s alNisẩ[4]: 176 adalah anak laki-laki saja. Pemahaman ini dilatarbelakangi oleh pengertian yang sudah biasa dipahami oleh orang arab bahwa walad itu adalah anak laki-laki. Pemahaman ini didukung lagi oleh HadisHadis yang menjelaskan tentang asabat (saudara lakilaki dan saudara perempuan mewarisi ketika bersamasama dengan anak perempuan) terutama sekali Hadis Ibn Mas' ûd. Q.s al-Nisẩ [4]: 176 menurut mereka belum jelas sehingga diperlukan Hadis yang akan menjelaskan apa yang dimaksud dengan kalâlah.

Sedangkan Syiah Imâmiyyah berpendapat bahwa Q.s al-Nisầ[4]: 176 sudah cukup untuk menjelaskan arti kalâlah. Pemahaman walad yang terdapat dalam ayat ini adalah anak laki-laki dan anak perempuan serta keturunan dari keduanya. Setiap anak mempunyai kedudukan yang sama dalam kewarisan kecuali dalam hal-hal yang sudah dijelaskan secara tegas dalam Alquran. []

\section{Pustaka Acuan}

'Abd al-Bâqî, Muhammad Fuâd, Mu'jam Al-Mufahras li Alfâzh al-Qur'ân al-Karîm, T.tp: Dâr al-Fikr, 1981.

'Asqalânî, al-, Ibn Hajar, Fath al-Bârî, T.tp, Al-Maktabah al-Salafiyyah, t.t.

Abu Bakar, Al Yasa, Ahli Waris Sepertalian Darah Kajian Perbandingan terhadap Penalaran Hazairin dan Penalaran Fikih Mazhab, Jakarta: INIS, 1998.

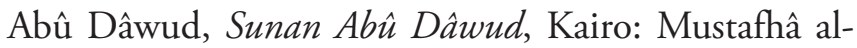
Bâb, 1952.

Baghdâdî, al-, Al-Âlûsî, Rûh al-Ma'ânî, T.tp: Dâr alFikr, t.t.

Hazairin, Hendak Kemana Hukum Islam, Jakarta: Tintamas, 1976.

Ibn al-'Arabî, A $\underline{b} k \hat{a} m$ al-Qur'ân, Bayrût: Dâr al-Fikr, 1998.

Ibn Katsîr, Tafsîr al-Qur'ân al-Azhîm, Bayrût: Dâr alFikr, t.t.

Ibn Manzhûr, Lisân al-Arab, Bayrût: Dâr al-Fikr, t.t.

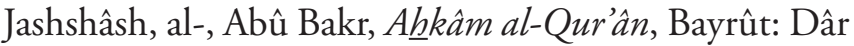
al-Fikr, t.t.

Jawziyyah, al-, Ibn Qayyim, I'lâm al-Muwaqqiîn 'an Rabb al-Âlamîn, Bayrût: Dâr al-Fikr, 1974.

Kirmânî, al-, Shahîh $\underline{h}$ al-Bukhârî bi Syarh al-Kirmânî, Kairo: al-Bâhiyyah al-Mishriyyah, 1937.

Mughniyyah, Muhammad Jawâd, Al-Ahwwâl alSyakhshiyyah, Bayrût: Dâr al-Ilmi, t.t. al-I'tishâm, 1999.

, Fiqih Lima Mazhab, diterjemahkan oleh Masykur, Jakarta: Lentera Basritama, 2000. 35 . 
Mûsâ, Muhammad Yûsuf, Al-Tirkah wa al-Mîrâts fì alIslâm, Mesir: Dâr al-Kitâb al-'Arabî, 1959.

Powers, David S., Studies in Qur'an and Hadith The Formation of The Islamic Law of Inheritance, London: University of California Press, 1979.

Qal'ah Jî, Muhammad Rawwâs dan Hâmid Shâdiq Qunaybî, Mu'jâm Lughah al-Fuqahâ,, Bayrût : Dâr al-Nafs, 1998.

Ridhâ, Muhammad Rasyîd, Tafsîr al-Qur'ân al- $\underline{\text { Hakim }}$ al-Syahîr bi al-Manâr, Kairo: Maktabah al-Bakarah, t.t.

Sarmadi, A. Sukris, Transendensi Keadilan Hukum Waris Islam Transformatif, Jakarta: PT RajaGrafindo Persada, 1997.

Sâyis, al-, Muhammad 'Alî, Tafsîr Ayât al-A $\underline{h k a ̂ m, t . t p: ~}$ t.p, t.t.

Syarifuddin, Amir, Pelaksanaan Hukum Kewarisan dalam Lingkungan Adat Minangkabau, Jakarta:
Gunung Agung, 1984.

-.----------, Pelaksanaan Hukum Kewarisan dalam Lingkungan Adat Minangkabau, Jakarta: Gunung Agung, 1984.

--------, Amir, Permasalahan dalam Pelaksanaan Faraid, Padang: IAIN IB Press, 1999.

Thabầthabầi, al-, Muhammad Husayn, Al-Mîzân fî̀ Tafsîr al-Qur'ân, Bayrût: Muassasah al-Â'lamî, t.t.

Thabarî, al-, Abû Ja'far Muhammad ibn Jarîr, Jâmi’ alBayân 'an Tảwîl Ayy al-Qurân, Bairût : Dâr al-Fikr, 1988.

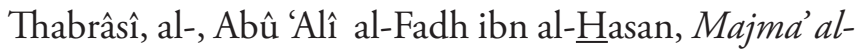
Bayân fî̀ Tafsîr al-Qur'ân, Bayrût: Dâr al-Fikr, 1986.

Thûsî, al-, Abû Ja'far Muhammad $\underline{\text { Hu} u s a y n ~ i b n ~ ' A l i ̂, ~} A l-$ Mabsûth fî Fiqh al-Imâmiyyah, Teheran: Maktabah al-Murtadhawiyyah, t.t.

Wensinck AJ, Mu'jâm al-Mufahras li Alfâzh al- $\underline{\text { Hadîts, }}$ Leiden: EJ Brill, 1967. 